Journal Homepage: http://pusdikra-publishing.com/index.php/jrss

\title{
The Effect Of Bingo Media To Improve Students Vocabulary Of The Eighth Grade Students At SMP S AL - Washliyah 27 Medan
}

\author{
Indah Eka Destry ${ }^{1}$, Yulia Sari Harahap ${ }^{2}$ \\ 1,2,Universitas Muslim Nusantara Al Washliyah
}

\section{Corressponding Author: 0 indahdestry975@gmail.com}

\section{ABSTRACT}

There are some factors have influenced in teaching vocabulary. The creative teacher will use teaching method which appropriate with the students condition in the class and can attract them to be more interested in learning English especially vocabulary achievement. The aim of this research is to find the significance of Bingo Media in teaching English Vocabulary was observed and analyzed from students of eighth grade of SMP S Al - Washliyah 27 Medan. In this research, Bingo as media was implemented with discussion method in order was chosen in this research to solve the problem. The method of this research is quantitative by taking 60 students as the sample. The population of this research was all grade VIII students and the sample of this research were VIII - A as the experiment class, grade VIII - B as the control class. Instrument of the research was used multiple choice about Descriptive text. After the research gave the treatment by used Bingo in teaching Vocabulary it showed that pre-test average score of experimental group was 83,67 and control group was 69. Meanwhile, the post-test average of experimental groups was 59,33 and control group was 55 . The research above the used Bingo and implementation of discussion method significantly affected on students vocabulary achievement. It could be concluded that the use of Bingo increasing students vocabulary achievement was affective. The result that found in this research was $t$ observed was 6,94 and $t$ table 2,00. It can state that there is significant difference between from students vocabulary scores taught by using Bingo and without Bingo. It means that Bingo Media are quite effective in improving students vocabulary achievement.

Keyword

Bingo, Vocabulary, Achievement

\section{INTRODUCTION}

Now days, an international language, English become important language. English help people communicate and interact with other people from different countries, and also to develop science, technology, art and culture. Knowing and mastering English language is given the benefits for students. Indonesian student study English as a foreign language in the elementary until university and also there are from kindergarten level. English have four skills : speaking, reading, listening, and writing, and Vocabulary is an important component to learn language . 
The students must able to master those skills, besides that the students also need to have a wide vocabulary, because vocabulary is a central to English language learning. Sufficient in vocabulary can help the students to express their own ideas and help to understand others. Thornbury (2002) states that While without grammar very little can be conveyed, without vocabulary nothing can be conveyed. This point reflects than even without grammar, with some useful words and expressions we can manage to communicate. Students often instinctively recognize the importance of vocabulary to their language learning. Vocabulary is words consist of meaning in order to express ideas and feeling so that the speaker and the listener can understand each other better.

Vocabulary is something crucial and indispensable for the students because the success of their study depends on the greater part of their vocabulary. Having a good vocabulary will help students to master language skills. It is almost impossible to learn on words. From the statement above it can be concluded that vocabulary is the first element in English that we should be mastered.

Even though we obviously know vocabulary is an important language component that should be mastered by students, but there are still many students who still lack of vocabulary. The lack of vocabulary causes students cannot are understand English well. It often occur, in teaching and learning activities there are still many students who can not answer teacher question and keep asking the teacher to translate the question into first language (Indonesia). When reading some text book the students do not know the meaning of the text that written in English, the same as their writing ability, when the teacher ask them to make a paragraph. The students really depend on the dictionary to make English word.

There are several reasons why students still lacking on vocabulary which are students feel bored because the technique by the teacher is monotonous, students are not interested in learning English and consider English as a difficult subject and lastly is the lack of use the media because the teacher only always relay on the speech method without involving media. It is necessary for English teacher to make materials more interesting and motivating so that the students can progress their vocabulary knowledge.

Many factors that affecting the students are difficulty in mastering the vocabulary. First, the students are difficult to understand and remember vocabulary. Many students were obtaining difficult when they speak because restrictiveness their vocabulary. Second, learning English was serious that made students depressed or afraid to develop their ability in vocabulary. Third, the students difficult to understand and try to memorize the vocabulary. They were 
easy to forget vocabulary has been taught or learn. Fourth, the students lazy to consult the dictionary and do not use vocabulary on daily communication. Fifth, students do not comprehend words meaning and the usage of the word in context.

To solve the problems above and to find the solution, then the researcher chose the thesis with the title " The Effect Of BINGO Media To Improve Students Vocabulary Of The Seventh Grade Students At SMP S Al Washliyah 27 Medan ". Because One of the ways that the teacher can use to make students fun, interactive, and empowering in learning vocabulary is by using the various vocabulary games (Farrel, 2009). From the opinion that related to the game, it is reckoned that a game is one of the effective ways in teaching vocabulary. We can say that by using a game in teaching vocabulary can help the students to improve their vocabulary skill.

Bingo is a game for the whole class that encourages students to study and review their vocabulary words. Bingo game is one of the games that can bring fun in the classroom. This game is easy to be played because it helps students memorize the words and the game need simple supplementary media as pencil and the concerning cards as the media of teaching. The teacher will let students make some efforts in order to solve the problem given. When students are actively involved in problem solving process, students will memorize the new words deeply and be able to recall them easily instead of when the teacher just tells the students some new words Not only can Bingo game build word recognition students' skill, it is also able to develop students' grammar understanding, spelling skills, listening skills, and teamwork.

\section{RESEARCH METHOD}

In this research the research will focus on Quantitative research. Cresswell (2003) stated, quantitative research "employ strategies of inquiry such as experimental and surveys, and collect data on predetermine instruments that yield statiscal data". The design of research is categorized into experimental research. It means that two kind of treatment applied. There are two groups of students namely experimental group and control group. The experimental group is the group that receives treatment by using BINGO Media. While, the control group is the group which receives treatment without BINGO Media. The design is as follow table : 
Table 1. The Design Of Research

\begin{tabular}{|l|l|l|l|l|}
\hline No. & Group & $\begin{array}{l}\text { Pre- } \\
\text { test }\end{array}$ & Treatment & Post-test \\
\hline 1 & Experimental group & $\mathrm{X}_{1}$ & With BINGO & $\mathrm{X}_{2}$ \\
\hline 2 & Control group & $\mathrm{Y}_{1}$ & Without BINGO & $\mathrm{X}_{2}$ \\
\hline
\end{tabular}

Note :

$\mathrm{X}_{1} \quad=$ Pre-test experimental group

$\mathrm{X}_{2} \quad=$ Post-test experimental group

$\mathrm{Y}_{1} \quad=$ Pre-test control group

$\mathrm{Y}_{2} \quad=$ Post-test control group

\section{RESEARCH RESULT AND DISCUSSION}

\section{The Data and Data Analysis}

The test was taken from the vocabulary test students. The students in this case the researcher obtained the students score after applying the post-test to the experimental and control group. The result of the pre-test and post-test of the two groups can be seen in the following table:

Table 2. The Score of Pre-test and Post-test of Experimental Group (VIII - A)

\begin{tabular}{|c|c|c|c|}
\hline No & Initial Name & Pre-Test & Post-Test \\
\hline 1 & ALA & 65 & 75 \\
\hline 2 & AKR & 50 & 80 \\
\hline 3 & AF & 55 & 90 \\
\hline 4 & AR & 50 & 95 \\
\hline 5 & DA & 75 & 95 \\
\hline 6 & DW & 50 & 85 \\
\hline 7 & DA & 50 & 75 \\
\hline 8 & GDS & 65 & 80 \\
\hline 9 & IP & 55 & 85 \\
\hline 10 & JS & 70 & 75 \\
\hline 11 & NS & 50 & 70 \\
\hline 12 & PHH & 65 & 80 \\
\hline 13 & RA & 50 & 95 \\
\hline 14 & RN & 65 & 80 \\
\hline 15 & RKAL & 55 & 80 \\
\hline 16 & RDS & 75 & 80 \\
\hline
\end{tabular}




\begin{tabular}{|l|c|c|c|}
\hline 17 & RAA & 50 & 75 \\
\hline 18 & MARS & 65 & 90 \\
\hline 19 & MRP & 50 & 95 \\
\hline 20 & MS & 55 & 70 \\
\hline 21 & MN & 60 & 80 \\
\hline 22 & NIT & 75 & 95 \\
\hline 23 & NA & p60 & 90 \\
\hline 24 & OL & 70 & 95 \\
\hline 25 & RF & 60 & 80 \\
\hline 26 & RIW & 50 & 75 \\
\hline 27 & SG & 70 & 85 \\
\hline 28 & SR & 65 & 90 \\
\hline 29 & SA & 50 & 80 \\
\hline 30 & SN & 55 & 90 \\
\hline & TOTAL & 1780 & 2510 \\
\hline
\end{tabular}

After collecting the data and scoring the experimental group's answer of pre test and post test that the researcher was given to the experimental group. It can show that the total scores of the experimental group test is for pre test, the experimental group got 1780 and for the post test they got 2510 .

Table 3. The Score of Pre-test and Post-test of Control Group (VIII-B)

\begin{tabular}{|c|c|c|c|}
\hline No & Initial Name & Pre-Test & Post-Test \\
\hline 1 & MA & 55 & 70 \\
\hline 2 & ARG & 50 & 65 \\
\hline 3 & AA & 60 & 75 \\
\hline 4 & AS & 60 & 70 \\
\hline 5 & BA & 55 & 60 \\
\hline 6 & FPL & 50 & 65 \\
\hline 7 & HF & 50 & 50 \\
\hline 8 & ISN & 50 & 65 \\
\hline 9 & IB & 55 & 60 \\
\hline 10 & IS & 55 & 70 \\
\hline 11 & MRP & 55 & 70 \\
\hline 12 & MIO & 50 & 65 \\
\hline 13 & MAP & 50 & 60 \\
\hline
\end{tabular}




\begin{tabular}{|c|c|c|c|}
\hline 14 & MP & 55 & 60 \\
\hline 15 & MRL & 50 & 75 \\
\hline 16 & MW & 55 & 75 \\
\hline 17 & NP & 65 & 80 \\
\hline 18 & PZ & 60 & 85 \\
\hline 19 & RRS & 65 & 90 \\
\hline 20 & RFR & 50 & 65 \\
\hline 21 & SAP & 55 & 70 \\
\hline 22 & SAN & 55 & 65 \\
\hline 23 & TFR & 60 & 75 \\
\hline 24 & TF & 55 & 70 \\
\hline 25 & WP & 60 & 75 \\
\hline 26 & SR & 50 & 55 \\
\hline 27 & TFR & 55 & 60 \\
\hline 28 & WP & 50 & 75 \\
\hline 29 & SK & 55 & 70 \\
\hline 30 & NR & 65 & 80 \\
\hline & TOTAL & 1655 & 2070 \\
\hline
\end{tabular}

The total scores of the control group test is for pre test the control group got 1655 and for post test they got 2070.

Table 4. The Differences of Score Between Pre-test and Post-test of the Experimental Group

\begin{tabular}{|c|c|c|c|c|}
\hline No & Initial Name & $\begin{array}{c}\text { Pre-Test } \\
\mathrm{T}_{1}\end{array}$ & $\begin{array}{c}\text { Post-Test } \\
\mathrm{T}_{2}\end{array}$ & $\begin{array}{c}\mathrm{T}_{2}-\mathrm{T}_{1} \\
\left(\mathrm{X}_{2}\right)\end{array}$ \\
\hline 1 & ALA & 65 & 75 & 10 \\
\hline 2 & AKR & 50 & 80 & 30 \\
\hline 3 & AF & 55 & 90 & 35 \\
\hline 4 & AR & 50 & 95 & 45 \\
\hline 5 & DA & 75 & 95 & 20 \\
\hline 6 & DW & 50 & 85 & 35 \\
\hline 7 & DA & 50 & 75 & 25 \\
\hline 8 & GDS & 65 & 80 & 15 \\
\hline 9 & IP & 55 & 85 & 30 \\
\hline 10 & JS & 70 & 75 & 5 \\
\hline 11 & NS & 50 & 70 & 20 \\
\hline 12 & PHH & 65 & 80 & 15 \\
\hline
\end{tabular}




\begin{tabular}{|l|c|c|c|c|}
\hline 13 & RA & 50 & 95 & 45 \\
\hline 14 & RN & 65 & 80 & 15 \\
\hline 15 & RKAL & 55 & 80 & 25 \\
\hline 16 & RDS & 75 & 80 & 5 \\
\hline 17 & RAA & 50 & 75 & 25 \\
\hline 18 & MARS & 65 & 90 & 25 \\
\hline 19 & MRP & 50 & 95 & 45 \\
\hline 20 & MS & 55 & 70 & 15 \\
\hline 21 & MN & 60 & 80 & 20 \\
\hline 22 & NIT & 75 & 95 & 20 \\
\hline 23 & NA & 60 & 90 & 30 \\
\hline 24 & OL & 70 & 95 & 25 \\
\hline 25 & RF & 60 & 80 & 20 \\
\hline 26 & RIW & 50 & 75 & 25 \\
\hline 27 & SG & 70 & 85 & 15 \\
\hline 28 & SR & 65 & 90 & 25 \\
\hline 29 & SA & 50 & 80 & 30 \\
\hline 30 & SN & 55 & 90 & 35 \\
\hline & & TOTAL & & 730 \\
\hline
\end{tabular}

$\mathrm{Mx}=\frac{\sum x}{N}$

$\mathrm{Mx}=\frac{730}{30}$

$\mathrm{Mx}=24,33$

Based on the table showed that, the deviation between pre-test and posttest in experimental group is 24,33

Table 5. The Differences of Score Between Pre-test and Post-test of the Control Group

\begin{tabular}{|c|c|c|c|c|}
\hline No & Initial Name & $\begin{array}{c}\text { Pre-Test } \\
\left(\mathrm{T}_{1}\right)\end{array}$ & $\begin{array}{c}\text { Post-Test } \\
\left(\mathrm{T}_{2}\right)\end{array}$ & $\begin{array}{c}\mathrm{T}_{2}-\mathrm{T}_{1} \\
\mathrm{Y}_{2}\end{array}$ \\
\hline 1 & MA & 55 & 70 & 15 \\
\hline 2 & ARG & 50 & 65 & 15 \\
\hline 3 & AA & 60 & 75 & 15 \\
\hline 4 & AS & 60 & 70 & 10 \\
\hline 5 & BA & 55 & 60 & 5 \\
\hline 6 & FPL & 50 & 65 & 15 \\
\hline 7 & HF & 50 & 50 & 0 \\
\hline
\end{tabular}




\begin{tabular}{|c|c|c|c|c|}
\hline 8 & ISN & 50 & 65 & 15 \\
\hline 9 & IB & 55 & 60 & 5 \\
\hline 10 & IS & 55 & 70 & 15 \\
\hline 11 & MRP & 55 & 70 & 15 \\
\hline 12 & MIO & 50 & 65 & 15 \\
\hline 13 & MAP & 50 & 60 & 10 \\
\hline 14 & MP & 55 & 60 & 5 \\
\hline 15 & MRL & 50 & 75 & 25 \\
\hline 16 & MW & 55 & 75 & 20 \\
\hline 17 & NP & 65 & 80 & 15 \\
\hline 18 & PZ & 60 & 85 & 25 \\
\hline 19 & RRS & 65 & 90 & 25 \\
\hline 20 & RFR & 50 & 65 & 15 \\
\hline 21 & SAP & 55 & 70 & 15 \\
\hline 22 & SAN & 55 & 65 & 10 \\
\hline 23 & TFR & 60 & 75 & 15 \\
\hline 24 & TF & 55 & 70 & 15 \\
\hline 25 & WP & 60 & 75 & 15 \\
\hline 26 & SR & 50 & 55 & 5 \\
\hline 27 & TFR & 55 & 60 & 5 \\
\hline 28 & WP & 50 & 75 & 25 \\
\hline 29 & SK & 55 & 70 & 15 \\
\hline 30 & NR & 65 & 80 & 15 \\
\hline & & TOTAL & & 415 \\
\hline
\end{tabular}

My $=\frac{\sum y}{N}$

My $=\frac{415}{30}$

$\mathrm{My}=13,83$

Based on the table above, the deviation between pre-test and post-test in control group score is 13,83 .

The Standart Deviation of the Control Group

Dy $=$ Deviation score of the control group

$\mathrm{Dy}^{2}=$ The Square of the deviation of the control group

Best on data above, the calculation is obtained as follows :

$X=730$

$\mathrm{Y}=415$ 


$$
\begin{aligned}
& \mathrm{Mx}=24,33 \\
& \mathrm{My}=13,83 \\
& \mathrm{Dx}^{2}=3236.67 \\
& \mathrm{Dy}^{2}=1184.17 \\
& \mathrm{Nx}=30 \\
& \mathrm{Ny}=30
\end{aligned}
$$

The data above than was calculated by applying t-test formula as follows :

$$
\begin{aligned}
& t=\frac{M x-M y}{\sqrt{ }\left(\frac{D x^{2}+D y^{2}}{N x+N y-2}\right)\left(\frac{1}{N x}+\frac{1}{N y}\right)} \\
& t=\frac{24,33-13,83}{\sqrt{\left(\frac{3236,67+1184,17}{30+30-2}\right)\left(\frac{1}{30}+\frac{1}{30}\right)}} \\
& t=\frac{10,50}{\sqrt{\left(\frac{4420,83}{58}\right)\left(\frac{2}{60}\right)}} \\
& t=\frac{10,50}{\sqrt{(76,22)(0,03)}} \\
& t=\frac{10,50}{\sqrt{2,29}} \\
& t=\frac{10,50}{1,51} \\
& t=6,94
\end{aligned}
$$

Based on the calculating of the t-test above, it was found that t-test is 6,94. The writer used the 5\% (0.05) alpha level of significant as usually educational research. Determining degree of freedom (df), with formula:

$$
\begin{aligned}
& \text { Df }=(\mathrm{Nx}+\mathrm{Ny})-2 \\
& =(30+30)-2 \\
& =\quad 58
\end{aligned}
$$

So, in the table $\left(t_{t}\right)$ is 2.002 for $5 \%$.

\section{Testing Hypothesis}

To test the hypothesis, the formula of $\mathrm{t}$-test and the distribution table of $\mathrm{t}$ critical value were applied. If observed is higher than t-table, it's mean that the null hypothesis is rejected and the alternative hypothesis is accepted. The fact of this research showed that $t$-observed is higher that $t$-table $(6,94>2.002)$. Therefore, $\mathrm{Ha}$ is accepted and $\mathrm{Ho}$ is rejected, in other words, teaching vocabulary using Bingo Media has more effective than without Bingo Media. 


\section{Discussion}

Based on the data analyzed and testing hypothesis, the writer findings of the research the effect of using Bingo Media to improve students vocabulary achievement were describe as the following :

1. The students who were taught by using Bingo Media got higher score than the students who were taught without Bingo Media.

2. The t-observed value was higher than $t$-table in which t-observed was 6,94 and t-table 2,00 $(6,94>2,00)$.

Based on the finding of research, it was found that students vocabulary achievement in experimental class taught by Bingo Media was higher then students in control class taught by discussion method. From the data i got it the lowest for pre-test in experimental group was 50 and the highest was 75 .

The lowest score of post test was 70 and the highest was 90. The lowest score for pre test of the control group was 50 and the highest was 65 . The lowest score of the post test was 60 and the highest was 90 .

For hypothesis by using t-test, it was found that t-observed 6,94 and $\mathrm{t}$ table 2,00. It means that Ha was accepted and Ho was rejected. In the other word, the vocabulary learning by using Bingo media in experimental class significantly affected on students vocabulary achievement in grade VIII - A.

From the result of the research, it can be seen that the teaching by using Bingo media for learning is more motived for students and can make students to be more active because they interested for the learning model apply.

\section{CONCLUSION}

Based on the data analysis, it can be conclude that students vocabulary achievement by using Bingo Media has a significant effect rather than in class that did not applying Bingo Media. The result of the conclusion of t-test is that $\mathrm{t}$-observed value : 6,94 with degree of freedom $(\mathrm{df})=58$ is higher than the value of $\mathrm{t}$-table $(2,00)$. In conclusion, those findings in imply that the alternative (Ha) : Bingo Media on vocabulary achievement is accepted and null hypothesis (Ho) is rejected. Therefore effect of applying Bingo Media has a significant effect on student vocabulary achievement.

\section{REFERENCES}

Arianto. (January 25,2003). A Study On the Use of Media In Teaching Vocabulary to Young Learners. http:/ / digilib.umm.ac.id/files/disk1/39/jiptummpp-gdl-s1-2005yopiariant-1937-Contets.pdf. 
Arikunto. (2006). Prosedur Penelitian Suatu Pendekatan Praktek. Jakarta: PT. Rineka Cipta.

Arsyad, A. (2013). Media Pembelajaran.

Asnawir, U. B. (2000). Media Pembelajaran. Jakarta Selatan: Ciputat Pers.

Australia., G. (2011, July 25). Vocabulary. http://www.decd.sa.gov.au/literacy/files/links/UtRP_1_4_v2>pdf,.

Bertram, C. e. (2010). "Using Media in Teaching".

Bintz, W. P. (2011). Teaching Vocabulary Accross the Curriculum. Middle School Journa, 44 - 53

Eviyuliawati, I. e. (2018). The Bingo Effect on English Speaking .

Finch, K. (2006). Meaningful Vocabulary Learning: Interactive Bingo.

Finch, K. (2006). Meaningful Vocabulary Learning: Interactive Bingo. .

Fitriya, A. (2016). The Effect Of Bingo Game On The Students Ability In Listening Skill at Eighth Graders Grammar Mastery at MTsNTulungagung in Academic Year 2016/2017.

Groller. (1974). The New Groller Webster International Dictionary Volume I E II. New York: Groller.

Hornby, A. S. (2002). Oxford Advanced Learner's Dictionary. New York: Oxford University Press.

Jackson, H. (2002). Grammar and Vocabulary. Routledge English Language Introductions: Routledge.

Khoirina, N. L. (2019). Using Speaking Bingo Game To Improve Students Speaking Ability.

Linse, C. T. (2005). Practical English Language Teaching Young Learners. New York : MC. Graw-Hill Companies,Inc.

Lopez, K. (2021, March 20). Materials and Methods for Teaching Reading. Retrieved from http:/ / hlperson.com/mt/archives/vocabulary.gif.

McCarten. (2007), June 10). Teaching Vocabulary. Retrieved from Lesson from the Corpus Lessons for the Classroom: http://www.cambridge.org/other_files/downloads/esl/booklets/McCar ten-Teaching-Vocabulary.pdf

Press, B. C. (2007., November 12). Building Vocabulary Teacher Tips. http://www.teachercreatedmaterials.com?curriculum_files/podcast/buil ding_vocabulary_podcast_handout.pdf.

Richardson, J. S. (2009). Reading to Learn in the Contect Areas(8th Ed.). Belmont:Cengage Learning.

Schmitt, N. (2000). Vocabulary in language teaching. New york: Cambridge University Press. 
Sidharta, A. (2005). Media Pembelajaran. Bandung: Departement Pendidikan Nasional.

Sudjana, e. a. (2000). Media Pembelajaran. Jakarta: Raja Grafindo Persada.

Supiyaningrum, R. (2011). Improving Students' Vocabulary Using Vocabulary.

Susanto, B. P. (2015). Improving Students Mastery Of English Synonyms And Antonyms Using Bingo And Domino Games.

Susilana, R. \&. (2009). Media Pembelajaran: Hakikat, Pengembangan, Pemanfaatan, dan Penilaian. . Bandung: CV. Wacana Prima.

Taoli, E. T. (2016). Increasing The Students Ability In Listening Skill Through Bingo Game At The Eight Grade Of SMPnEGERI 1 alasa iN 2015/2016.

Thornbury, S. (2002). How to teach vocabulary. Cambridge University: English Person Education Limited.

Tozcu, A. \&. (2004). Successful learning of Frequent Vocabulary through CALL Also Benefits Reading Comprehension and Speed. In Computer Assisted Language Learning (pp.473-495). 